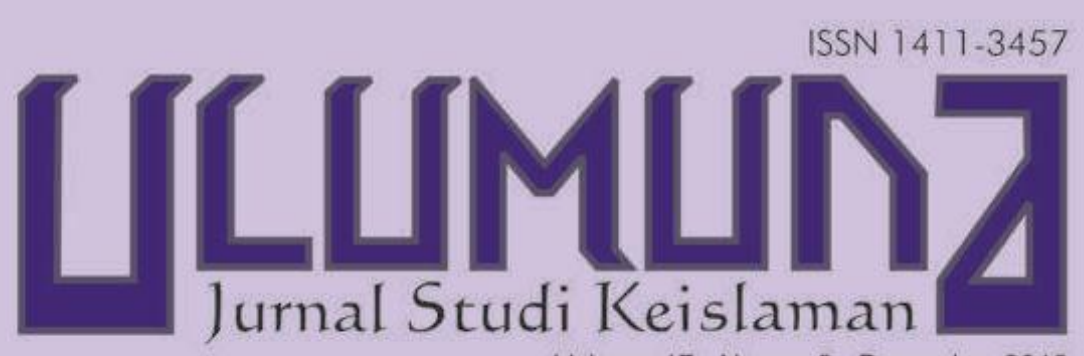

Volume 17· Nomor 2 - Desember 2013

TERAKREDITASI [3, SK Dirjen Dik: Kenmikind Nomor: 56 DIKTIKep 2012. Targgal 24 junt 2012

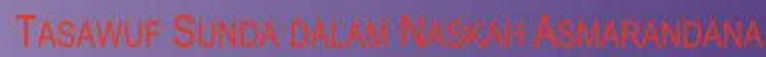
$767(6)$

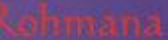

(s):

DALAM TRADISI KEAGM

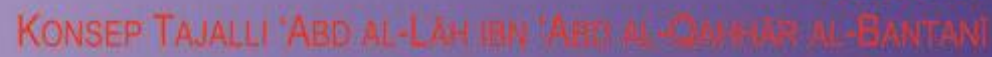

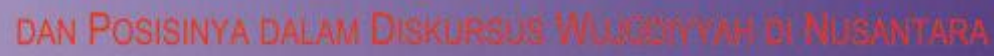

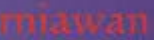

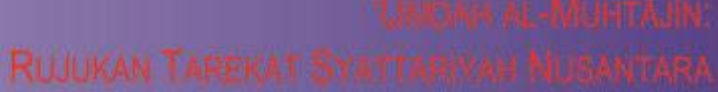

manherit

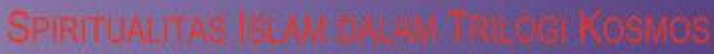

1) thits

YOWMAN:

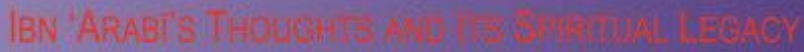

3ेputra

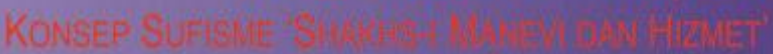

GUIEN

(umayi

Acoxuma

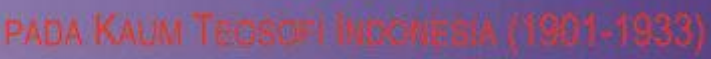

Babei

BASAWUF

Tanany

upinkat 


\section{DAFTAR ISI}

\section{Pedoman Transliterasi}

\section{1-258 • Jajang A Rohmana}

"Tasawuf Sunda dalam Naskah Asmarandana

Ngagurit Kaburu Burit (OR. 7876)”

259-274 • Mashadi

"Konteks dan Corak Mistisisme Islam

dalam Tradisi Keagamaan Masyarakat Gorontalo"

275-302 • Ade Fakih Kurniawan

"Konsep Tajalli 'Abd al-Lāh ibn 'Abd al-Qahhār

al-Bantanī dan Posisinya dalam Diskursus

Wujūdiyyah di Nusantara"

303-322 • Damanhuri

“Umdah al-Muhtàjīin:

Rujukan Tarekat Syattariyah Nusantara"

\section{3-346 • Munawir Haris}

"Spiritualitas Islam dalam Trilogi Kosmos"

347-358 - Hans Abdiel Harmakaputra

"Becoming a Perfect Human:

Ibn 'Arabî's Thoughts and Its Spiritual Legacy"

359-386 • Sulaiman Al-Kumayi

"Konsep Sufisme 'Shakhs-i Manevi dan Hizmet'

Muhammad Fethullah Gülen"

387-420 • Media Zainul Bahri

"Gagasan Pluralisme Agama

pada Kaum Teosofi Indonesia (1901-1933)"

421-440 • Lalu Supriadi

"Studi Komparatif Pemikiran Tasawuf

al-Ghazali dan Ibn Taimiyah"

\section{LAMPIRAN-LAMPIRAN}




\section{PEDOMAN TRANSLITERASI}

\begin{tabular}{|c|c|c|c|c|c|c|}
\hline 1 & $=$ & $\mathbf{a}$ & & $\dot{\varepsilon}$ & $=$ & $\mathrm{g}$ \\
\hline ب & $=$ & b & & ف & $=$ & f \\
\hline$ت$ & $=$ & $\mathbf{t}$ & & ق & $=$ & $q$ \\
\hline$\dot{H}$ & $=$ & th & & ك & $=$ & $\mathbf{k}$ \\
\hline ج & $=$ & $\mathbf{j}$ & & J & $=$ & 1 \\
\hline$\tau$ & $=$ & ḥ & & s & $=$ & $\mathrm{m}$ \\
\hline$\dot{\tau}$ & $=$ & $\mathbf{k h}$ & & $\dot{ن}$ & $=$ & $\mathbf{n}$ \\
\hline$د$ & $=$ & d & & 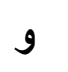 & $=$ & $\mathbf{w}$ \\
\hline$\dot{j}$ & $=$ & dh & & ○ & $=$ & $\mathbf{h}$ \\
\hline$\jmath$ & $=$ & $\mathbf{r}$ & & $\varepsilon$ & $=$ & , \\
\hline j & $=$ & $\mathbf{z}$ & & ي & $=$ & $\mathbf{y}$ \\
\hline س س & $=$ & s & & & & \\
\hline 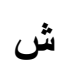 & $=$ & sh & \multicolumn{4}{|c|}{ Untuk Madd dan Diftong } \\
\hline ص - ص & $=$ & ș & i & $=$ & \multicolumn{2}{|c|}{$\bar{a}$ (a panjang) } \\
\hline ض ض & $=$ & d & إي & $=$ & \multicolumn{2}{|c|}{$\overline{1}$ (i panjang) } \\
\hline b & $=$ & $t$ & أو & $=$ & \multicolumn{2}{|c|}{ ù (u panjang) } \\
\hline ظ & $=$ & z & او & $=$ & \multicolumn{2}{|c|}{ aw } \\
\hline$\varepsilon$ & $=$ & ' & أي & $=$ & \multicolumn{2}{|l|}{ ay } \\
\hline
\end{tabular}

Contoh penulisan dengan transliterasi:

(a'üdhu bi al-Lāh min al-shaytān al-rajim); اعوذ بالله من الشيطان الرجيم

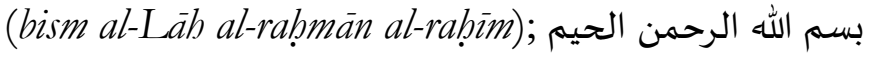

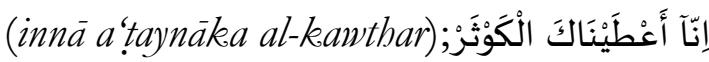

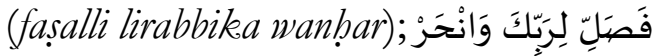

(șabāḥ al-khayr). صبباح الخير 


\title{
GAGASAN PLURALISME AGAMA PADA KAUM TEOSOFI INDONESIA (1901-1933)
}

\author{
Media Zainul Bahri
}

(Fakultas Ushuluddin dan Filsafat UIN Syarif Hidayatullah Jakarta Email: mediazain_75@yahoo.com)

Abstract: This article elucidates the idea of religious pluralism among Indonesian theosophies society (MTI), an association of well-educated people of Nusantara from 1901 through 1933, whose members were dominated by the high-class of Javanese and Sumatran people, Dutch and other Europeans. It argues that MTI's ideas about pluralistic and inclusive religious perceptions and attitudes were indeed influenced by perennialism, religious humanism, Javanese Islam and Sufism that accepted religious pluralism. MTI's deep religious outlooks and insights resulted from mixed ideas coming from diverse socio-cultural backgrounds: Europe, America, India, China and indigenous Nusantara traditions which emphasizes the principles of harmony.

Abstrak: Artikel ini akan mengurai gagasan pluralisme agama pada Masyarakat Teosofi Indonesia (MTI), suatu perkumpulan masyarakat terpelajar di Nusantara yang ekesis pada rentang waktu 1901 bingga 1933, yang anggotanya didominasi oleh kaum priyayi Nusantara Jawa dan Sumatera), orang-orang Belanda dan Eropa non-Belanda. Gagasan mereka yang bergairah mengenai pandangan dan sikap keagamaan yang inklusif-pluralis pada masa itu sesunggubnya terkait erat dengan ajaran perenialisme, humanisme religius, Islam Jawa, dan pandangan sufistik sufisufi Islam yang mereka anggap banyak mengidealisir gagasan mengenai pluralisme agama. Pandangan keagamaan yang mendalam dan wawasan yang luas, pada MTI labir sebagai hasil dari pergumulan banyak ide dan perjumpaan dengan bangsa-bangsa: Eropa, Amerika, India, Cina, dan kekayaan kultur bangsa sendiri yang condong kepada harmoni.

Keywords: teosofi, pluralisme, Tuban, sufi, mistis, Nusantara, priyayi, perenialisme. 
TULISAN ini akan mendeskripsikan suatu pandangan keagamaan yang bercorak inklusif-pluralis yang ditunjukkan oleh sekumpulan masyarakat sipil (civil society) atau katakanlah paguyuban yang dikenal dengan sebutan Gerakan Teosofi Indonesia, atau dalam tulisan ini saya menyebutnya sebagai Masyarakat Teosofi Indonesia (MTI) pada periode 1901-1933. MTI dapat dikatakan sebagai "mutiara terpendam" dalam suatu episode sejarah sosial-keagamaan atau gerakan spiritual Indonesia sebelum kemerdekaan. Mungkin tidak banyak orang Indonesia yang mengetahui eksistensi MTI di masa sebelum kemerdakaan dulu sebagai paguyuban yang menghendaki kemajuan pola pikir dan mental kaum pribumi dan terwujudnya persaudaraan universal di antara para pemeluk agama Nusantara yang majemuk. Mungkin pula, sejauh penelusuran saya, MTI adalah sekelompok civil society yang pertamakali mempelopori model studi agama-agama dengan pendekatan mistik atau perenial, mengenal dan mendalami aspek syariat dan hakekat agama-agama di Indonesia dengan cara mendengar (belajar) langsung dari tokoh agama masing-masing sehingga lahir pemahaman yang utuh dan obyektif mengenai agama yang dikaji.

Dalam praktek aktivitasnya, para anggota teosofi biasanya berkumpul secara berkala untuk berdiskusi atadiu mengadakan "pengajian" di loji-loji (lodges). Ada loji Bogor, Betawi, Cirebon, Bandung, Pasuruan, Semarang, Purwokerto, Pekalongan, Wonogiri, Surabaya dan hampir semua kota kecil dan besar di Jawa memiliki loji. Disebabkan ajaran pokoknya mengenai kemajuan (progress), filsafat-mistik, sains dan persaudaraan universal membuat banyak kaum muda dan tokoh penting dalam pembentukan negara Indonesia kala itu menjadi simpatisan dan anggota teosofi. Sebut saja nama-nama beken seperti Haji Agus Salim, Radjiman Wedjodiningrat, Achmad Subardjo, Cipto Mangunkusumo, Sutomo, Muhammad Yamin, Suwardi Suryaningrat, Raden Sukemi (ayah Sukarno), Datuk St. Maharadja. Nama-nama lain seperti Ki Hadjar Dewantara, Muhammad Hatta dan Sukarno juga memiliki hubungan erat dengan teosofi. Belum lagi para ningrat Jawa dan Sunda sebagai tokoh-tokoh lokal yang ikut bergabung. 
Iskandar Nugraha melalui karyanya yang sangat baik, Teosofi, Nasionalisme \& Elite Modern Indonesia (2001 \& 2011), menunjukkan bahwa melalui organisasi teosofi, beberapa kaum terpelajar Indonesia menemukan identitas diri mereka, merasakan persamaan nasib, dan seolah diajak menemukan identitas kebangsaan (diri mereka) sendiri. Karena itulah Iskandar berkesimpulan bahwa Gerakan Teosofi memiliki kontribusi yang sangat penting bagi kebangkitan nasional Indonesia. ${ }^{1} \mathrm{Di}$ sisi lain, kebangkitan itu sesungguhnya berhubungan dengan agama, dan teosofi berperan di situ. Dalam sejarah konvensional Indonesia, jika membicarakan kebangkitan nasionalisme, selalu yang dirujuk adalah Boedi Oetomo (BO), Indische Partij, Jong Islamische Bond, Jong Java, Jong Soematra, jong Ambon dan semacamnya. Organisasi keagamaan tidak pernah disinggung. Padahal, pada level elit ada Gerakan Teosofi dan level bawah ada NU dan Muhammadiyah yang juga menyemai bibit-bibit cinta bangsa alias nasionalisme di masa revolusi fisik dulu. Pada level tengah barulah Budi Utomo dan "kawankawan"nya.

Saya merasa beruntung menemukan majalah-majalah (istilah yang digunakan saat itu untuk menyebut jurnal) yang mereka terbitkan mulai tahun 1900 hingga 1954 yang merekam sebuah episode penting dalam kehidupan sosial-keagamaan Indonesia, di antaranya Pewarta Theosophie Boeat Tanah Hindia Nederland (atau PTHN, Bahasa Melayu, 21 Volume, 188 Nomor, 1911-1938), Teosofie In Nederland Indie: Theoshopie Di Tanah Hindia Nederland (Bahasa Belanda dan Melayu, 80 Nomor, 1918-1925), Theosophie in Nederlandsch Indie (atau TINI, Bahasa Belanda, 1912-1930), Kumandang Theosofie (atau KT, Bahasa Melayu, 6 Volume, 46 Nomor, 1932-1937) dan Persatoean Hidoep (atau PH, Bahasa Melayu, 11 Volume, 109 Nomor, 1930-1940), Pewarta Theosofie Boeat Indonesia (atau PTBI, Bahasa Melayu, 1912-1930), dan Pewarta Theosofi Tjabang Indonesia (atau PTTI, Bahasa Melayu,

${ }^{1}$ Iskandar Nugraha, Teosofi, Nasionalisme \& Elite Modern Indonesia (Depok, Komunitas Bambu, 2011), 76, 88. Cetakan pertama karya Nugraha itu berjudul, Mengikis Timur \& Barat: Gerakan Theosofi \& Nasionalisme Indonesia (Jakarta: Komunitas Bambu, 2001). 
1954).2 Publikasi MTI yang berbahasa Melayulah yang saya jadikan sumber utama dalam tulisan ini.

Dalam atmosfir keagamaan yang cenderung eksklusif dan intoleran seperti yang kita saksikan dalam satu dasawarsa terakhir, rasanya pandangan dan sikap keagamaan MTI yang inklusif-pluralis kembali relevan dan aktual untuk diangkat dalam diskursus keagamaan kita saat ini.

\section{Pengertian Teosofi}

Istilah teosofi dalam diskursus filsafat dan mistisisme tentu saja merupakan nama yang sudah sangat tua dan bahkan identik dengan dua kajian itu. Mari kita lihat seluk beluk pengertian itu seperti yang dipahami (diyakini) oleh kaum teosofi sendiri. Menurut Blavatsky, "theos" artinya tuhan (god, bukan God), "sophid" artinya Kebijkasanaan (wisdom). Tapi, theos di sini merujuk kepada atau dalam pengertian "seorang dewa" dalam bahasa Yunani, salah satu dari makhluk-makhluk Ilahi dan bukan dalam pengertian "Tuhan" seperti yang dipahami oleh orang-orang sekarang, bukan "Tuhan Personal." Karena itu, teosofi bukanlah "Kebijaksanaan Tuhan" seperti yang diterjemahkan oleh sebagian besar orang, melainkan "Kebijaksanaan Ilahi" seperti yang dimiliki oleh para dewa. Dalam bahasa lain, Blavatsky menyebut "teosofi" sebagai "Pengetahuan Ilahi”" atau "Sains Ilahi". 3

Dalam pengertian MTI, sophie atau sophia dimaknai sebagai "Ilmu" atau "Pengetahuan" dan "Theos" adalah "Tuhan" atau "Allah" (dengan T dan A besar). Menurut mereka, teosofi adalah Ilmu atau Hikmat Allah, ${ }^{4}$ diartikan juga Pengetahuan tentang Tuhan; alam beserta isinya menjadi tanda yang meyakinkan bahwa Tuhan itu ada. Makna terdalam dari teosofi adalah Ilmu Kesempurnaan. ${ }^{5}$ Pada MTI, Tuhan dipahami sebagai "Tuhan

${ }^{2}$ Meskipun PTTI ini terbit pada tahun 1954, namun isinya tidak berbeda dengan jurnal-jurnal (majalah) serupa yang terbit pada masa prakemerdekaan.

${ }^{3}$ Helena Petrovna Blavatsky, The Key to Theosophy (USA, Theosophical University Press, t.t.), 2.

${ }^{4}$ C.W. Leadbeater, "Kitab Theosofie," dalam PTHN (1915), 15.

5R.M. Wongsodilogo, "Djalan Oetama," dalam PTHN (1921), 53. 
Personal" seperti yang dipahami dan dianut oleh agama-agama konvensional di Nusantara, bukan tuhan dalam pengertian Blavatsky sebagai "tuhan impersonal." Penjelasan Helena Blavatsky mengenai seluk beluk teosofi memang lebih rumit dari apa yang dipahami oleh MTI karena sang Madam lebih menukik kepada penjelasan-penjelasan yang sangat esoterik, hal itu terjadi karena salah satu alasannya adalah "pengalaman mistik" sang madam. Dalam beberapa surat dan ceramahnya, Blavatsky mendefinisikan teosofi sebagai Koan; suatu istilah dalam Budhisme Zen. Koan berarti sebuah formulasi, sebuah titik penting menuju kebenaran yang Absolut. Koan adalah sebuah misteri yang tak bisa dipecahkan hanya dengan penjelasan dan alasan logis, tetapi hanya dapat dipahami oleh kesadaran pada levelnya yang paling dalam yang melampaui konseptualisasi dan penjelasan intelek. ${ }^{6}$

Kata teosofi menurut Blavatsky diwariskan dari para filsuf Alexandria, yaitu para filsuf pencinta kebenaran, Philaletheians, dari kata 'mencintai' (phil) dan 'kebenaran' (aletheia). Kata teosofi berasal dari abad III Masehi yang mulai diperkenalkan oleh Ammonius Saccas ${ }^{7}$ dan murid-muridnya yang memulai mendiskusikan sistem filsafat eklektik. ${ }^{8}$ Tujuan sistem filsafat ini pertama-tama menanamkan kebenaran-kebenaran moral luhur tertentu pada murid-muridnya yang semua adalah "para pencinta kebenaran." Karena itu, semboyan yang digunakan oleh Perhimpunan Teosofi adalah "Tidak ada agama yang lebih tinggi dari Kebenaran (There is no religion higher than Truth, Satyan Nasti Paro Dharmab)." Tujuan utama para pendiri mazhab teosofi eklektik adalah juga salah satu dari tiga tujuan Perhimpunan Teosofi sebagai penerus modernnya, yaitu mendamaikan semua agama, aliran dan bangsa dibawah sebuah sistem etika umum berdasarkan pada kebenaran abadi. ${ }^{9}$

${ }^{6}$ Blavatsky, The Key ..., 11.

${ }^{7}$ Seorang filsuf yang dilahirkan sebagai seorang Kristen dan salah satu tokoh komunitas Philaletheians.

${ }^{8}$ Ibid., 2.

Ibid., 2. Menurut Herman de Tollenaere, sejak awal teosofi memang mencampurkan berbagai macam ajaran agama, filsafat, tradisi kuno dan banyak sumber lain. Doktrin-doktrin teosofi diambil dari ajaran Hermes, Phytagoras, Plato, Plotinus dan ajaran filsafat Yunani lain serta sistem 
Ammonius Saccas merupakan tokoh yang mencoba menjembatani berbagai perbedaan pada beragam agama besar kuno dan berbagai aliran/sekte di Mesir dan Palestina. Hal itulah yang akan dilakukan oleh Perhimpunan Teosofi masa kini. Menurut Blavatsky, kaum Neo-Platonis adalah sebuah perkumpulan besar termasuk berbagai filsuf religius dan para teosof. Pada masa itu, Aristobulus menyatakan bahwa etika Aristoteles mewakili ajaran 'dalam/batin' (esoterik) Hukum Musa, Philo Judaeus telah berusaha mendamaikan atau menjembatani kitab Taurat (Pentateuch) dengan filsafat Pythagoras dan Plato, dan Yosephus membuktikan bahwa kaum Essenes dari Carmel merupakan peniru serta pengikut para penyembuh Mesir Huno (Therapeutae). Saat inipun agama-agama besar, aliran-aliran dan sekte-sekte adalah ranting-ranting kecil atau tunas-tunas yang tumbuh di dahan-dahan lebih besar, namun harus disadari bahwa tunas-tunas dan dahan-dahan itu muncul dari pohon yang sama yaitu "Agama Kearifan" (Wisdom Religion). Bukti mengenai satunya Agama Kearifan menjadi tujuan ajaran Ammonius yang mencoba menarik kaum Gentile, Kristen, Yahudi, dan penyembah berhala untuk mengesampingkan pendirian (dogma) serta perselisihan mereka, lalu hanya mengingat bahwa mereka semua sejatinya memiliki kebenaran yang sama dengan baju-baju yang berbeda dan mereka adalah anak-anak dari ibu yang sama. Ajaran Kebijaksanaan Agung ini kemudian diteruskan dan didukung oleh para filsuf agung seperti kedua Bapak Gereja, Clement dari Alexandria dan Athenagoras, kaum Rabbi terpelajar, Akademi

\footnotetext{
keagamaan Romawi, Tarot dari permainan kartu abad pertengahan Italia, model segitiga dan loji (lodge) dari gerakan Freemason dan Mason, percaya kepada dunia cahaya Astral dan roh-roh dari ajaran spiritualisme, mengambil konsep Malaikat dan Dewa-dewa dari ajaran Dionysius tahun 500 SM, konsep Arahat dari agama Buddha, doktrin pertarungan kekuatan (tuhan) putih dan kekuatan hitam dari agama Zoroaster dan Mani; dari Hindu mengambil reinkarnasi, karma dan lain-lain. Karena sinkretisme yang mempesona ini membuat banyak tokoh dan orang terpelajar dari seluruh dunia tertarik untuk menjadi anggota teosofi. Herman Arij Oscar de Tollenaere, The Politics of Divine Wisdom, Theosophy and Labour, National, and Women's Movements in Indonesia and South Asia 1857-1947 (Leiden: Universiteit Nijmegen, 1996), 25-7.
} 
Plato, para pendukung filsafat perenial, kaum pluralis dari berbagai agama dan keyakinan, namun kaum teosofi dan para penerus ajaran Agama Kearifan itu dihujat dan dimusuhi. Menurut Blavatsky fakta permusuhan itu menunjukkan bahwa 1500 tahun yang lalu orang-orang terlihat lebih toleran dibanding manusia-manusia di abad 'pencerahan' ini. ${ }^{10}$

Dari namanya tampak bahwa teosofi berarti ilmu esoterik (batin) atau ilmu kenyataan ${ }^{11}$ yang akan menjelaskan dimensi terdalam (yang esensi) dari dogma-dogma kering dan kaku. Teosofi akan membentuk seseorang menjadi bijak, welas asih atau cinta terhadap sesama, suci bersih jalan pikiran dan sikapnya. ${ }^{12}$ Jadi, pada tataran praktek, teosofi, seperti ditegaskan oleh Blavatsky, adalah praktek hidup penuh cinta kasih, kesucian hati dan diri, tidak rakus, tidak selalu mementingkan diri sendiri dan memiliki solidaritas sosial. ${ }^{13}$ Karena itu, Perkumpulan Teosofi ini kadang disebut juga Persaudaraan Putih yang Mulia karena fokusnya pada nilai-nilai dan praktek hidup mulia.

Dalam banyak publikasi MTI, terutama yang ditulis oleh orang-orang Islam anggota teosofi, teosofi berarti juga tasawuf, ilmu dan praktek tasawuf, atau jalan sufi. Tasawuf sebagai ilmu dan jalan inilah yang harus ditempuh oleh orang-orang teosofi untuk sampai kepada Kenyataan, Kebenaran, dan Kesempurnaan. Secara umum, teosofi adalah kebijaksanaan Ilahi dan segala peristiwa yang diterangkan oleh Tuhan, pengetahuan tentang semesta alam dan semesta hidup, yang coba ditelaah dari dalam ke luar, dari Kenyataannya yang gaib ke keadaannya yang terang. Maka yang dicari adalah Kenyataan; Kenyataan di dalam agama, filsafat dan ilmu pengetahuan agar tercapai suatu kebijaksanaan dalam hidup, perilaku dan tindakan. Hal yang terpenting dalam teosofi adalah ajarannya bahwa apapun yang diterima oleh seseorang baik ajaran agama, filsafat, dan ilmu pengetahuan jangan dipercaya begitu saja, tetapi coba diselami

10Ibid., 3.

${ }^{11}$ Kijahi Somo Tjitro, "Djalan Menoentoet Elmoe Kenjataan," dalam PTHN (1915), 121.

${ }^{12}$ Ibid.

13"Pidatonja Dr. Besant pada congres tahoenan jang ke-56 di Adjar, 24 December 1931," dalam KT (1932), 106. 
Kebenarannya atau Kenyataannya. ${ }^{14}$ Pengetahuan apapun semestinya "dirasakan" kebenarannya atau "dialami” langsung kenyataannya, setidaknya dikritisi sampai sedalam-dalamnya. Hal ini mungkin yang paling sulit dilakukan untuk menjadi teosof sejati. Namun, itulah ajaran sejati teosofi.

\section{Munculnya Gerakan Teosofi di Indonesia}

Gerakan Teosofi didirikan pertamakali di kota New York, Amerika Serikat, tahun 1875 oleh seorang wanita bangsawan keturunan Rusia yang memiliki bakat mistik atau supranatural yang luar biasa bernama Helena Petrovna Blavatsky (1831-1891), yang dibantu dua orang Amerika, yakni Henry Steel Olcott dan W.Q. Judge. Segera setelah organisasi tersebut berdiri, H.S. Olcott diangkat menjadi Presiden perkumpulan yang kemudian diberi nama Theosophical Society (TS). Tahun 1879 pusat TS dipindahkan oleh Madam Blavatsky dari New York ke Adyar, India. Tahun 1895, TS memasuki babak baru karena munculnya seorang tokoh baru, yaitu Annie Bessant. Tokoh inilah yang membawa TS berpengaruh secara tajam, tidak saja di India, namun menyebar ke seluruh dunia, termasuk Indonesia. ${ }^{15}$

Menurut Iskandar Nugraha, bukti-bukti pasti yang mengungkap kemunculan awal Gerakan Teosofi di Indonesia hampir tidak ada kecuali beberapa catatan yang hanya memberi gambaran bersifat umum. Salah satu gambaran umum itu memberi petunjuk bahwa Gerakan Teosofi di Hindia (Indonesia) pertamakali didirikan di kota Pekalongan, Jawa Tengah, 8 tahun sesudah teosofi berdiri di Amerika tahun 1883, dan sebagai bagian dari Gerakan Teosofi Nederland, dan tentu saja semuanya menginduk kepada gerakan Internasional yang berpusat di Adyar, India. Loji (lodge) teosofi di kota kecil ini dipimpin seorang bangsawan Eropa, Baron van Tengnagel. Tahun 1883 belum dapat dipastikan sebagai awal Gerakan Teosofi di Hindia secara pasti, sebab sumber lain menyebutkan tahun 1881. Yang dapat diapstikan oleh Nugraha adalah bahwa kemunculan awal Gerakan itu berada di akhir abad XIX. Saat

${ }^{14} \mathrm{KT}$ (1931), no. 1, 45. Derun, "Meditasi Untuk Permulaan (II)," dalam PTTI, no. 27, (1954), 18-9.

${ }^{15}$ Nugraha, Teosofi ..., 5-7. 
itu, setidaknya teosofi telah menarik perhatian sebagian masyarakat Jawa, terutama di Jawa Tengah. Siapa, apa, dan bagaimana latar belakan pendiriannya belum diperoleh petunjuk yang pasti. Yang diketahui adalah bahwa The Pekalongan Theosophical Society ini dipimpin seorang Kapitein Infantri tentara Hindia Belanda yang pernah ditempatkan di Dinas Topografi. Organisasi tersebut secara sah diakui kantor pusat teosofi di Adyar dan izinnya ditanda tangani Kolonel Olcott. ${ }^{16}$

Namun sesungguhnya, jauh sebelum H.P. Blavatsky mendirikan teosofi di New York (1875), sang Madam diberitakan pernah berkunjung ke Hindia lebih dari satu kali. Menurut majalah teosofi, Lucifer, perhatian sang Madam cukup tinggi kepada Hindia sebelum ia mendirikan teosofi, terutama tentang kemungkinan nilai-nilai Jawa yang menurutnya dapat dijadikan penyumbang ajaran teosofi. Dalam rangka itulah, pada tahun 1852-1860, Blavatsky mengunjungi Candi Mendut dan Borobudur, dan sempat singgah di Pekalongan dan bermalam di Pesanggrahan Limpung di bawah gunung Dieng. Pada tahun 1862, ia kembali berkeliling Pulau Jawa dan diberitakan menyinggahi banyak tempat di Jawa. Menurut Iskandar, kemungkinan munculnya Gerakan Teosofi awal di Pekalongan dapat dikaitkan dengan fakta kunjungan Blavatsky di Jawa, dan kemungkinan kuat kegiatan Gerakan Teosofi paling awal di Hindia ini masih terbatas pada aspek kebatinan saja seperti yang berlangsung di pusatnya saat itu. ${ }^{17}$ Mengenai kegiatan detail organisasi teosofi di akhir abad XIX di Hindia serta aktivitas Baron van Tenggnagel hingga wafatnya, menurut Iskandar masih gelap alias belum terkuak. Yang diketahui Baron meninggal di Bogor tahun 1893. ${ }^{18}$

Secara ringkas dapat dikatakan bahwa di akhir abad XIX hingga tahun 1933, Gerakan Teosofi Indonesia merangkak maju secara pelan namun pasti; dari tahun ke tahun mendapat simpati

16Ibid., 8-9. Karya Iskandar ini merupakan satu-satunya referensi bahasa Indonesia yang menjelaskan cukup detail dan luas mengenai sejarah teosofi Indonesia. Dalam tulisan ini tidak akan dijelaskan secara detail perkembangan hingga pudarnya gerakan ini di akhir tahun 1930.

${ }^{17}$ Ibid., 8-9, 38.

18Ibid., 9. 
dan anggota yang terus membengkak. Pada masa keemasannya, kira-kira tahun 1910 hingga 1930, teosofi membangun banyak organisasi sayap demi merealisasikan semangat persaudaraan, menyebarkan paham teosofi, dan memberdayakan kaum pribumi, terutama dalam bidang pendidikan dan pengembangan kualitas moral ketimuran yang adiluhung. Beberapa organisasi penting di bawah teosofi adalah: (1) Bintang Timoer (1911), yang mengkhususkan pengajaran dan praktek tasawuf dan kebatinan, (2) Moeslim Bond (1924), wadah bagi kaum Muslim anggota teosofi untuk belajar menerima kenyataan akan perubahanperubahan dunia, (3) Mimpitoe atau M 7 (1909), yaitu organisasi yang berfokus memerangi 7 hal: (a) Main (berjudi), (b) Minoem (mabuk), (c) Madon (main perempuan), (d) Madat (mabuk karena menghisap ganja dan sejenisnya), (e) Maling, (f) Modo (mencela atau mengumpat karena dengki dan benci), (g) Mangani (makan berlebihan dari yang dibutuhkan), (4) Perbimpunan Toeloeng-Menoeloeng (1909), (5) Widija-Poestaka (1909), yaitu organisasi yang bertujuan mengumpulkan setiap pengetahuan zaman kuno yang ditemukan di Hindia (Nusantara). Upaya ini dilakukan semata-mata untuk melindunginya dari kemusnahan. (5), NIATWUV (NederlandschIndische Wereld Afdeling Theosofische Wereld Universiteit Vereeniging), yaitu Perhimpunan Universitas Dunia Teosofi Cabang Hindia Belanda yang menyelenggarakan sejumlah sekolah dan mendukung pendirian sejumlah pranata pendidikan di Hindia. Salah satu sekolah yang didirikan dan menjadi favorit adalah Sekolah Arjuna (Ardjoena-scholen) (1914). ${ }^{19}$ Sekolah-sekolah yang didirikan kaum teosofi diberi nama Sekolah Arjuna karena tokoh ini sangat digandrungi tidak hanya di dunia wayang, namun juga oleh orang-orang teosofi, dan wayang adalah salah satu media penyebaran paham teosofi yang terfavorit, ${ }^{20}$ (6) Organisasi Ati Soetji (1914), yang berupaya memajukan kehidupan kaum wanita dan usaha-usaha sosial lainnya. Tiga tujuan Ati Soetji; menjunjung derajat kebangsaan; memajukah onder-wijs

${ }^{19} I b i d .$, 19-20. Secara luas Nugraha menjelaskan organisasi-organisasi diatas pada bab "Gerakan Kegiatan Teosofi di Indonesia (1901-1933)," 4566.

${ }^{20}$ Ibid., 12. 
(pengajaran); dan membantu ekonomi kaum Bumiputra. Selain itu juga bertujuan mengadakan perlindungan, pertolongan, dan tunjangan kepada mereka yang terkena celaka atau sengsara karena kejahatan. ${ }^{21}$

Dalam hal keanggotaan, penting dipertanyakan siapakah mayoritas anggota teosofi Indonesia? Iskandar Nugraha memiliki penjelasan yang cukup jelas. Hasil risetnya menunjukkan bahwa Gerakan Teosofi di Hindia (Indonesia) terdiri orang-orang Belanda asli, Bumiputera, Cina dan IndoEropa (keturunan Eropa). Sampai tahun 1900-an mayoritas Indo sebagai bagian dari masyarakat Eropa Hindia Belanda memiliki kedudukan sosio-ekonomi yang buruk dan teralienasi. Hal ini karena mereka ditolak oleh "ayah" mereka sendiri bangsa Eropa dan tuntutan-tuntutan mereka tak pernah digubris. Di sisi lain, mereka juga sulit menyesuaikan diri dengan kaum Bumiputera karena posisi mereka yang tetap sebagai orang Eropa. Dengan keadaan ini, kaum Indo yang menjadi penganjur Gerakan Asosiasi mendominasi keanggotaan teosofi. Dalam gerakan ini, mereka agaknya menemukan konsep yang membawa mereka dekat dengan kalangan Bumiputera dan dapat memperjuangkan persamaan seperti yang dikatakan Ricklefs, "Theosophy was one of the few movements which brought elite Javanese, Indo-Europeans and Dutchmen together in this period..."22

Golongan Bumiputera merupakan golongan kedua terbanyak menjadi anggota teosofi. Di antara kalangan Bumiputera, orang Jawa merupakan kelompok yang paling dominan menjadi anggota. Konsep teosofi dan pendekatan para pemimpin teosofi adalah dua faktor penyebab utama tertariknya kaum priyayi Jawa terhadap gerakan ini. Ajaran-ajaran teosofi yang bersifat esoterik, spiritual atau "kebatinan" cocok dengan budaya para priyayi Jawa yang menyukai mistik. Ajaran teosofi dianggap banyak kesamaannya dengan ajaran-ajaran rahasia yang

${ }^{21}$ Ibid., 13. Dalam Pewarta Theosofie Boewat Tanah Hindia Nederland (1919) dijelaskan beberapa organisasi sayap teosofi yang telah didirikan, yaitu (1) Wedijapoestaka, (2) Perdamean Sadoenia, (3) Mim-7 (mimpitoe), dan (4) Bintang Timoer. Lihat, PTHN (1919, no. 5), 68-9.

${ }^{22}$ M.C. Ricklefs, The History of Modern Indonesia (California: Stanford University Press, 2008), 198. 
terdapat dalam kitab-kitab kuno berbahasa Jawa (sebagai warisan mulia leluhur orang-orang Jawa). Para priyayi Jawa itu, meskipun menganut agama Hindu, Islam atau Kristen, pada kenyataannya mereka adalah panteis yang berhasil mengkombinasikan kepercayaan dari agama resmi mereka dengan pemikiran leluhur (nenek moyang) yang memiliki sifat mistik. Itulah sebabnya, menurut Nugraha, mengapa Gerakan Teosofi meskipun kemudian menyebar luas di Nusantara, pengaruh terkuatnya justru terdapat di Jawa Tengah dan Jawa Timur. ${ }^{23}$

Menurut Nugraha, masuknya seorang Bumiputera dalam lingkungan teosofi yang kebanyakan anggotanya dari kalangan bangsawan tinggi (priyayi) tentu menjadi suatu gengsi atau kebanggaan tersendiri. Anggota-anggota pertama dari kalangan priyayi yang kemudian turut menyebarluaskan ajaran teosofi di kalangan pelajar adalah tokoh-tokoh berkharisma tinggi, baik karena kedudukan, pendidikan maupun karena pemikiranpemikiran mereka. Faktor inilah yang membuat kaum terpelajar non-priyayi (umumnya orang Jawa) tertarik untuk bergabung dengan teosofi. Kesempatan bergaul dengan kaum priyayi tinggi dan orang-orang Eropa (terutama Belanda) berkedudukan tinggi yang mau menghargai keberadaan mereka, merupakan hal yang sangat langka pada masa itu. Terlebih lagi, Gerakan Teosofi juga memiliki fasilitas intelektual yang memadai, misalnya perpustakaan. C.L.M. Panders, penulis The Life Times of Soekarno (1974), seperti dikutip Nugraha, menceritakan bahwa "Soekarno menghabiskan waktu berjam-jam di Perpustakaan Theosophical Society di mana ia memperoleh akses karena keanggotaan ayahnya. Di sanalah ia bergumul dengan pemikiran tokoh-tokoh politik termasyhur dalam sejarah." 24 Selain perpustakaan yang memiliki koleksi literatur yang lengkap, Gerakan Teosofi (lewat organisasi NITV), juga menyediakan sarana bagi arena diskusidiskusi terbuka, baik dalam studie-klasse atau dalam bentuk openbare lezing (ceramah terbuka). ${ }^{25}$

Watak kolonial yang diwarnai oleh pembagian masyarakat berdasarkan warna kulit yang tajam (colour line division) dan

${ }^{23}$ Nugraha, Teosofi ..., 30-1.

${ }^{24}$ Ibid., 31.

${ }^{25}$ Ibid., 44. 
prinsip dasar Gerakan Teosofi yang tidak memandang warna kulit, ras, agama dan suku-bangsa, semakin mendorong kalangan Bumiputera terpelajar bergabung dalam organisasi ini. Berkaitan dengan dominasi orang-orang Jawa, pada kongres teosofi pertama di Yogyakarta pada 1907, dari 78 orang utusan yang hadir di rumah M.R.T. Sosronegoro, 19 priyayi bergelar "Raden" (R), "Raden Mas" (RM), dan "Raden Ngabehi" (R.Ng). Sementara 17 lainnya adalah priyayi wanita. Meskipun Jawa amat dominan, di antara anggota-anggotanya ada juga yang berasal dari kelompok suku lain seperti Sunda, Minangkabau, Melayu, bahkan Manado dan Ambon. Berdasarkan ladenlijst (daftar keanggotaan) tahun 1914 dan 1915, selain para priyayi Jawa, terdapat banyak kaum bangsawan dari Sumatera Barat (Minangkabau). Hal ini dibuktikan dengan adanya gelar-gelar yang ditulis sesudah nama mereka, yaitu "Galar Sutan," "Galar Datuk," "Galar Marah," "Galar Tan," "Datuk Rangkayo," dan lainnya. ${ }^{26} \mathrm{Di}$ antara orang Sumatera Barat yang menjadi anggota adalah Haji Agus Salim, tokoh-pejuang dan pahlawan nasional, dan Dt. Sutan Maharadja, seorang tokoh pergerakan nasional yang sangat terkenal. ${ }^{27}$ Orang-orang Sunda yang menjadi anggota juga banyak yang bergelar "Raden." 28

Secara detail, Herman Tollenaere menguraikan bahwa pada tahun 1930 keanggotaan teosofi Indonesia mencapai puncaknya, yaitu 2090 orang, yang terdiri dari: (1) 1006 orang-orang Eropa yang lebih dari $50 \%$-nya adalah orang-orang Belanda, (2) 876 orang-orang asli Indonesia, (3) 208 orang-orang asing dari Asia, dan (4) 190 orang-orang Cina dan India (orang-orang India berjumlah sekitar 20 orang dari angka itu). Secara geografis, keanggotaan (dan loji-loji) berpusat di Jawa, dan secara sosial, sebagian besar anggota orang Indonesia adalah para priyayi Jawa, sebagian kecil orang-orang Sumatera Barat dan ningrat Bali. ${ }^{29}$

Selain dari gambaran keanggotaan di atas, jika kita menelaah lebih lanjut tulisan-tulisan tentang Islam dalam jurnal-jurnal

\footnotetext{
26Ibid., 34-5.

${ }^{27}$ Ibid., 32.

${ }^{28}$ Ibid., 35.

${ }^{29}$ Herman Tollenaere, Indian Thought in the Dutch Indies, The Theosophical Society, II AS Newsletter Online, no. 23 (2000), 1.
} 
teosofi, kita juga menemukan satu kelompok lain, yaitu kaum santri Muslim. Kelompok santri ini bisa berasal dari golongan priyayi, meskipun sangat jarang, atau berasal dari kaum terpelajar non-priyayi. Dalam stratifikasi masyarakat Jawa, kaum santri ini kedudukannya lebih tinggi dari orang-orang kecil/biasa (wong cilik) tetapi tetap lebih rendah dari kaum priyayi. Mengenai keanggotaan kaum santri Muslim terpelajar ini, Agus Salim menyatakan: "Saya bergabung ke dalam Theosophical Society karena saya melibat mereka mengakomodasi banyak kaum Muslim, khususnya Muslim yang diasingkan karena pendidikan Baratnya namun masih berpegang kuat pada tradisi. Mereka adalab orang-orang yang tertarik pada Theosophical Society." 30

\section{Teosofi dan Paham Pluralisme Agama}

\section{Satu Tuban Banyak Nama}

Salah satu kegiatan pokok MTI adalah mempelajari agamaagama, terutama agama yang hidup Nusantara. Pelajaran itu berisi dua hal pokok, yaitu mengkaji aspek mistik agama-agama dan melakukan studi perbandingan agama. Namun, studi Perbandingan Agama yang mereka lakukan lebih banyak dalam bentuk mencari (menemukan) kesamaan-kesamaan ajaran agama-agama dibanding perbedaannya. Karena itu, dalam studi agama-agama atau Perbandingan Agama pada MTI, model pembahasan yang menekankan titik-temu dan kesatuan esensial agama-agama merupakan corak yang sangat dominan. Kita akan menemukan uraian yang luas sekali akan hal ini. Inilah salah satu doktrin inti Gerakan Teosofi seperti yang dijelaskan oleh Blavatsky tentang sistem filsafat eklektik dengan Ammonius Saccas_-salah satu tokohnya yang paling menonjol-yang mengajarkan bahwa agama-agama dan keyakinan, baik yang besar maupun yang kecil-merupakan ranting-ranting, tunas dan dahan-dahan dari pohon yang sama, yaitu "Agama Kearifan."

Karena itu, konsep MTI mengenai Satu Tuhan banyak nama tentu berpijak kuat kepada mistik atau aspek esoterik yang menjadi perhatian utama mereka. Pertama-tama, kita harus melihat konsep mereka tentang Tuhan. Pada teosofi Blavatsky,

\footnotetext{
${ }^{30}$ Nugraha, Teosofi ..., 32.
} 
Tuhan dipahami secara Impersonal. Kata "Tuhan" tidak dipahami secara Personal sebagaimana dalam agama-agama besar, namun "Ketuhanan" yang merujuk kepada dewa-dewa masa Yunani ribuan tahun yang lalu, ${ }^{31}$ jadi, ketuhanan yang abstrak. Tetapi, karena MTI telah dipengaruhi oleh agama-agama mapan Indonesia, maka "Tuhan" pada MTI sama dengan Tuhan dalam agama-agama yang dipahami oleh masyarakat Indonesia. Dengan mengutip al-Qur'an, Al-Kitab (Perjanjian Baru), Sutta Pitaka, Amos (Yahudi), Gathas (Zoroaster), Bhagawadgita dan Sukhmani, Guru V (Sikh), MTI meyakini bahwa Tuhan adalah Esa, Pencipta semesta dan semua makhluk, Penguasa dan Raja di langit dan bumi, Maha Agung, Sumber dan Tempat Kembali semua hal dan memiliki banyak nama. ${ }^{32}$ Jadi, Tuhan bersifat sangat Personal. Di sisi lain, dengan mengutip ajaran kaum sufi Muslim dan Hindu, orang-orang teosofi meyakini bahwa Tuhan tak dapat dijangkau oleh intelek dan segala macam konseptualisasi. Akal tidak bisa menemukan jawaban pasti dari mana asal Tuhan, bagaimana bentuknya, berapa umurnya dan lain-lain. Tuhan Ada, dapat dirasakan tapi tak dapat dilihat, tak bisa dijangkau dengan ukuran manusiawi. ${ }^{33}$ Karena Kebesaran dan Keagungan Tuhan sulit dipahami, maka kaum beriman membutuhkan nama, sifat atau simbol yang mudah dipahami demi berkomunikasi dengan-Nya. Di sini kaum teosofi meyakini bahwa meski Tuhan itu Esa, tapi para pemeluk agama memanggilnya dengan banyak nama, seperti terbaca dalam kutipan di bawah ini:

Di dalem kitab-kitab Koeno soedah tertoelis Toehanlah tjoemah ada Satoe. Orang Blanda panggil di mana nama "God", orang Islam menjeboet "Allah taalah", orang sindhoe namain "Ishwara", orang Tionghoa namain "Kwan-shai-Yin Thian", dan lain-lain, tetapi biar nama berbeda, jang Maha Koeasa tjoemah satoe. ${ }^{34}$

Akan segala bangsa berlain-lainan lafalnja atau katanja boeat menjeboet asma Toehan: Bangsa Arab menjeboet Allah. Bangsa Belanda menjeboet God. Bangsa Jahoedi menjeboet Jehovah. Agama Brahma

${ }^{31}$ Blavatsky, The Key ..., 2.

32PTTI (1954), no. 29, 15-6.

${ }^{33}$ A. Latif, “Ada," dalam PTHN (1922), no. 5, 67-8.

${ }^{34}$ H.E. van Motman, "Kepada Toean redacteur soerat kabar Pewarta Theosophie," dalam PTHN (1912), 123-4. 
menjeboet Brahman. Agama Khong Hoe Tjoe menjeboet Thau. Bangsa Griek mengatakan Theo...tidak ada perkataan jang boleh diboeat menjeboet nama Toehan, jang tjotjok seperti rasanja. Lebih djelas: segala seboetan itoe boekan namanja jang sedjati. Njatalah berlainlainan bahasanja, tetapi maksoednja boleh dikatakan SAMA. ${ }^{35}$

Makna yang sama terlihat juga dalam kutipan ini:

Menoeroet jang terseboet diatas, dari pemandanganja Bangsa Blanda (kristen), bangsa Tiong Hoa dan Bangsa kita (Islam) dari hal Toehan sama, djadi tida berbeda, tjoema perkataanja sadja berlainan. ${ }^{36}$

Sekali lagi, dengan bersandar kepada keyakinan kaum sufi Muslim, seorang anggota teosofi dari Islam meyakini akan keragaman nama-nama Tuhan Yang Esa itu, seperti yang ia tulis:

Toehannja kaoem Soefie itoe, ja Toehannja masing-masing igama dan Toehannja sekalian orang manoesia. Nama: Allah, God, Dieu, Brahma, atau Bhagwan itoe tidak dibeda-bedakan sedjatinja oleh kaoem Soefie. Semoea nama ini dan nama lain-lainja itoe, djoega nama Toehannja kaoem Soefie, akan tetapi Toehan itoe tidak dibatasi nama tadi. ${ }^{37}$

Dalam mencari Tuhan, seorang mistikus yang melakukan perjalanan spiritual sampai ke rahasia gaib di dalam dirinya, maka ia menemukan Yang Esa dalam banyak wajah dan nama. Ada yang menyebutnya "Natur" ada pula yang memanggilnya "Allah," "God," "Tuhan," dan lain-lain.38 Yang Esa itu Dia-Dia juga, tidak berbeda dan bukan yang lain. Sekali lagi, kita lihat seorang anggota teosofi memaparkan keyakinannya:

Allah itoe tjoemah satoe, tetapi wadjahnja amat banjak. Sebagi halnja seorang kepala roemah tangga jang mempunjai isteri, anak soedara dan kawan-kawan, jang diseboet laki oleh si isteri, Bapa oleh si anak dan Toewan oleh si kawan, begitoe djoega halnja Allah, ada jang menjeboet Goesti, ada jang Bapa. ${ }^{39}$

35S. Si Pitjik, "Membandingkan Agama," dalam PTHN (1926), No.7, 100. Seorang penulis Tionghoa (beragama Konghucu) juga menyebut nama Gusti, Thian, Monade, Kristus dan Allah ketika merujuk kepada Tuhan yang Sama yang memberi keselamatan. N, "Seng-To! Kow-Li!," dalam PTHN (1927), 124.

36.M., "Satoe Pokok," dalam PTHN (1922), no. 1-2, 21.

${ }^{37}$ Inayat Khan, "Soefie," dalam PTHN (1922), no. 5, 66.

${ }^{38}$ N., “ Djalannja Mentjarik Ingsoen," dalam PTBI (1930), no. 3, 34.

${ }^{39}$ Louis Baehler, "Gadadhara atau Ramakrisjna," dalam PTHN (1916), 98. 
Dari sini, orang-orang teosofi menunjukkan konsep mengenai "Kesatuan Ketuhanan." Konsep ini memiliki tiga pengertian. Pertama, Tuhan itu benar-benar Satu, hanya namaNya saja yang dipanggil berbeda-beda. Dalam bagian lain-yang belum disebut diatas-orang Konghucu menunjukkan adanya konsep kesatuan Tuhan dalam agama Islam, Konghucu dan Tao. Kedua, ada keyakinan bahwa Tuhan dan manusia sejatinya adalah satu. Manusia berasal atau lahir dari Tuhan. Dalam diri manusia terdapat natur Tuhan. Ketiga, dengan konsep ini muncul konsep mengenai "orang suci penyelamat" atau "ratu adil." Dari konsep kesatuan ketuhanan atau Satu Tuhan banyak nama, muncul keyakinan bahwa Tuhan yang Esa itu mengutus orang-orang suci untuk menyelamatkan dunia sebagai bentuk manifestasi nama-nama-Nya. Tentang orang-orang suci penyelamat itu, seorang anggota mengatakan:

Dari itoe (satu Tuhan banyak nama) djangan toeroet orang hoeroehara... Moedah-moedahan soepaja semoea orang manoesia bisa dan soeka toeroet jang baik dan jang pantes, soepaja jang Termoelia lekas bisa dateng di doenia, boeat bikin betoel kliroe dan bikin damai di mana jang roesoeh. Jaitoe bangsa Christen panggil "De Christus", jang bangsa Islam seboet "Imam mahdi", dan rahjat poelo djawa namaken "Sri Toendjoeng Eroe Tjokro", dan "ratoe Adil", bangsa Sindoe kata "djagat Goeroe", igama Boeddha seboet "Bodhisatwa", "Maitreija", bangsa Parsi ngoetjap "Shaosijant" bangsa Jahoedi "Masiha", dan bangsa lain ada poela namanja. ${ }^{40}$

Pemahaman akan kesatuan ketuhanan atau Satu Tuhan banyak nama diharapkan oleh MTI agar umat manusia dapat hidup rukun dan menjauhi konflik (atau "hoeroe-hara" dalam bahasa MTI), para pemeluk agama yang beragam agar memiliki keyakinan bahwa agama dan keyakinan mereka berasal dari Sumber yang Sama sehingga tidak perlu membesar-besarkan perbedaan yang hanya akan melahirkan ketegangan dan konflik intra dan antar pemeluk agama. Demikianlah, dalam diskursus filsafat perenial, manusia, sepanjang sejarahnya, menyebut Tuhan Yang Esa dan Mutlak itu dengan berbagai nama dan istilah, namun secara substansial, beragam nama itu menunjuk kepada zat yang sama. Tuhan sebagai wujud Absolut sekaligus

40Motman, “Kepada Toean ..., 124. 
Dia Yang Dikenal inilah yang dijadikan obyek pujaan karena fungsi dan posisi-Nya yang diyakini oleh manusia sebagai pencipta dan penguasa jagad semesta ini. Dari sisi tanž ĭh, Tuhan diyakini sebagai yang teramat jauh, bahkan tidak terjangkau (transenden), namun pada level tasybih, Dia juga sekaligus berada bersama manusia; di sini bahkan di dalam diri manusia (imanen). Karena Yang Satu dan Absolut itu tidak mungkin ditaklukan oleh kapasitas nalar manusia yang amat terbatas, maka Dia ditangkap kehadiran-Nya (penampakan-Nya) melalui simbolsimbol atau nama-nama yang kemudian disakralkan sehingga di mata manusia lalu muncul bentuk tuhan-tuhan yang plural. ${ }^{41}$

\section{Kesatuan Esensi dan Hubungan Substansial Para Utusan Tuban}

Dengan konsep di atas, doktrin mengenai kesatuan esensial agama-agama menjadi tak terelakkan. Dalam banyak sekali publikasi, MTI mengumandangkan kesatuan esensial keyakinan dan kepercayaan terdalam meski bentuk agama berbeda-beda. Kita kutip pandangan mereka:

Tetapi memang soenggoeh tidak ada bedanja didalam kepertjajaan apa djoegapoen, memang sama, biarpoen namanja berjenis-jenis jang dipilihnja... ${ }^{42}$

Ini semoea mertandakan, jang broederschap itoe tida boeat satoe groep atau golongan kepertjajaan, atau satoe agama sadja, akan tetapi boeat semoea orang, walaupoen kepertjajaannja berbeda-beda...dan lagi, djikalau orang, apa agamanja sadja, memperloekan mempeladjari lain agama-agama atau mentjoekoepi pengadjarannja agamanja sendiri tamtoelah mendapat perasaan, jang satoe sama jang lain tida ada bedanja. Tjoema vorm atau ragangannja alias koeroengannja ada perbedaan. ${ }^{43}$

Kesatuan esensial itu tentu berarti dimensi batinnya. Pada dimensi ini semua agama dan keyakinan berasal dari Tuhan Yang Sama dan memiliki tujuan yang sama pula. Mereka mengatakan, "Dari itu haroeslah samoea igama kita pandang maksoednja (Tasaoefnja), djanganlah kita pandang dari labirnja sadja, sebab samoea barang labir

${ }^{41}$ Komaruddin Hidayat dan Muhammad Wahyuni Nafis, Agama Masa Depan: Perspektif Filsafat Perennial (Jakarta: Gramedia, 2003), 69-70.

42S.M., "Djalan Kesempoernaan," dalam PTHN (1926), no. 10, 140.

${ }^{43}$ N. "'Sekarang Datang Swara Baroe, Apa Soedah Tahoe?" dalam PTBI (1929), no. 10, 147-8. 
tida aken langgeng; jang langgeng tjoemah batinnja."44 Agama-agama yang beragam dan berbeda sejatinya-dalam bahasa mereka adalah "prabot menjembah kepada Toehan, mana sadja jang dipilih." Orang dapat memilih agama yang dirasa cocok baginya sebab, "Samoea agama tiada ada djeleknja atawa lebib baik dari pada jang lain, mengartinja ija-itoelah sama sadja." 45 Jadi, sumber dan tujuan dari semua agama adalah sama, itu-itu juga, yaitu Tuhan.

Dalam hal kesatuan esensi ini, kita menemukan banyak sekali tulisan orang Islam dalam publikasi-publikasi MTI yang merujuk kepada ajaran-ajaran kaum sufi-dan sebagiannya telah kita lihat dalam penjelasan diatas. Para penulis Muslim itu meyakini bahwa mutiara-mutiara ajaran kaum sufi, apakah Ibn 'Arabī, Rūmī, al-Ghazālī dan al-Junayd sesuai dengan doktrin dan misi Gerakan Teosofi yang menghendaki perdamaian dunia dengan cara mengeksplorasi ajaran kesatuan esensi dalam agama-agama dan pesan kenabian. Menurut para penulis Muslim itu, bahasa kaum Sufi adalah bahasa hati/batin yang dapat mengerti nama-nama atau manifestasi yang berbeda, seperti pengertian Kristus: siapa yang menyandang nama Kristus? Menurut mereka, kaum sufi tidak terikat pada nama. Semua nama, apakah itu Kristus, Nabi, Priester, Konig, Guru Selamat, Verlosser, Bruidegom, dan Geliefde, semua itu esensinya satu. Kaum Sufi mengerti semua isi dari nama-nama tersebut. ${ }^{46}$

Konsep Islam mengenai kesatuan esensial agama-agama dan hubungan esensial atau kesatuan pesan para nabi kental sekali dalam tulisan-tulisan orang Islam anggota teosofi. Dengan pemahaman Islam yang esoterik, mereka menegaskan bahwa semua nabi yang diutus Tuhan membawa isi ajaran yang sama meskipun doktrin lahiriahnya berbeda. Seorang anggota menulis:

Nabi siapa sadja jang toeroen di doenia itoe, semoea mengerdjakan Kemaoeannja Toehan. Walaupoen pengadjarannja Nabi-Nabi tadi lahirnja berlainan, dari sebab tiap-tiap bangsa mempoenjai rasa perbedaan dan keperloeannja djoega berlainan. Akan tetapi ISI-nja Agama-Agama jang teradjarkan itoe sama sadja alias SETALI TIGA OEWANG...djikalau orang maoe mempeladjari Mystiek-nja atau

\footnotetext{
44Siswosoeparto, “Kabar dari M 7,” dalam PTHN (1912), 140.

45Djojodiredjo, “Wadjibnja Orang Hidoep," dalam PTHN (1912), 45.

46J.M., "Hal Rasoelallah,” dalam PTHN (1920), 87.
} 
Occult-nja alias peladjaran gaib-nja itoe Agama-Agama: Itoe semoea asalnja, pokoknja, toeknja dari SATOE, boekan? ${ }^{47}$

Lalu ia mengutip surat al-Baqarah ayat 87 mengenai keyakinan kesatuan pesan kenabian di atas. Semua pemeluk agama, dalam keyakinan mereka, jika benar-benar mempraktekkan ajaran agama dan memahaminya secara mendalam, maka yang dirasakan adalah kesatuan isi pada agamaagama yang berbeda bentuknya tersebut. Seorang penganut teosofi menulis:

Djikalau selimut jang menggelapi mata terbuka tentoelah kelihatan, jang ISI-nya Agama Islam sama sadja dengan ISI-nja Agama B. Apa jang tida bikin sama? Sabetoelnja semoea sama, akan tetapi tjoema orang jang ta' maoe bikin sama. Dari sebab kebodohan jang menggelapkan pikiran. Djikalau orang mendjalanken betoel Agamanja dan mengatahoei ISI-nja Agamanja, tentoelah ta' bisa memperbedaken satoe sama lain Agama. ${ }^{48}$

Tentu yang dimaksud 'kebodohan yang menggelapkan pikiran' adalah mereka yang tidak paham atau tidak mau paham dan merasakan ajaran batin, esoterik atau terdalam agama, dan tidak mau mempelajari dan memahami esensi agama-agama lain. Bodoh bagi mereka yang hanya terpaku pada aspek syariat atau eksoterik, dan bahkan menuhankannya. Orang-orang teosofi bahkan menjamin jika seorang penganut agama memahami dan meyakini rasulnya secara lahir dan batin, maka:...soedah tentoe mengerti bahwa lain-lainnja itoe sama sadja, semoewa-semoewanja asal dari satoe sadja, jaitoe Jang Maha Agoeng. ${ }^{49}$ Selanjutnya, bagi MTI-khususnya mereka yang Muslim--semua agama adalah Islam. Dalam pengertian pasrah, selamat, aman, damai, dan penuh cinta kasih, semua agama berarti Islam, dan jika semua pemeluk agama sungguh mempraktekkan ajaran agama mereka, maka pengertian-pengertian Islam tersebut memang menunjukkan bahwa sejak awal agama mereka berarti Islam. Tentu, Islam disini dalam pengertiannya sebagai kualitas atau sikap personal dan bukan sebagai institusi. Seorang teosof Muslim mengatakan:

\footnotetext{
${ }^{47}$ N., “Djagad Goeroe," dalam PTHN (1927), no. 8, 203.

48Ibid., 201.

${ }^{49}$ Baehler, "Gadadhara ..., 52.
} 
Djikalau Agama-Agama jang doeloe-doeloe itoe bukan Islam, soedah tentoe Nabinja poen pendjoesta, sedang K.N. (mungkin maksudnya Kanjeng Nabi) Mohamad soeroe kepada kita pertjaja kepada semoea Pesoeroeh Toehan (Nabi-Nabi?) ${ }^{50}$

Karena itu, bagi kaum Muslim anggota teosofi, semua utusan Tuhan membawa ajaran yang mulia, benar dan memiliki kesamaan-kesatuan dengan ajaran Nabi Muhammad. Jika Nabi Muhammad menyuruh kaum Muslim, tidak hanya mempercayai, namun mencintai dan menghormati ajaran para nabi terdahulu, maka murid-murid atau pengikut sekalian para nabi terdahulu harus juga dicintai, dihormati dan diajak hidup rukun damai oleh kaum Muslim. Jika kaum Muslim mencintai dan menghormati Tuhan, maka manusia siapapun dan makhluk Tuhan lainnya harus dicintai juga. ${ }^{51}$ Inilah ajaran Nabi Muhammad dan ajaran para nabi lainnya.

Dengan ajaran itu, muncul pula doktrin mengenai kesinambungan dan kesatuan esensial kitab suci. MTI meyakini bahwa pertama, semua kitab suci: Taurat, Injil, Weda, Upanisad, Bhagawad Gita, al-Qur'an, Tripitaka, dan lain-lain merupakan benar-benar kitab suci, berisi ajaran mulia untuk para nabi dalam konteks yang berbeda-beda, namun berasal dari Tuhan Yang Sama. ${ }^{52}$ Kedua, jika dipahami, didalami dan dipraktekkan oleh setiap pemeluk agama, semua kitab suci itu merupakan penerang bagi hidup yang gelap gulita dan akan membawa keselamatan sejati. ${ }^{53}$ Ketiga, semua kitab suci sederajat; tidak ada yang lebih tinggi atau lebih rendah antara satu dengan yang lainnya. Semua penganut agama yang beragam hendaknya mempelajari dan melakukan studi banding terhadap dua atau beberapa kitab suci itu. ${ }^{54}$ Keempat, dengan semua kitab suci itu, Tuhan masih terus bersuara dan berbicara kepada semua kaum beriman yang

50W1, “Haroes Terpoedji," dalam PTHN (1927), no. 6, 129.

${ }^{51}$ Lid TVTKL, "Katerangan Dari Goeroe Kita," dalam PTHN (1927), no. 1,15 .

52Pitjik, "Membandingkan ..., 104.

53Tanpa penulis, " Goenanja Roepa-Roepa Pengadjaran Didalam KitabKitab Tasaoef,” dalam PTHN (1920), 108.

54Pitjik, "Membandingkan ..., 104. 
membacanya atau berdialog dengan-Nya melalui kitab-kitab itu. 55

Berbagai doktrin MTI tentang kesatuan esensial agamaagama, pesan kenabian dan kitab-kitab suci sesungguhnya merupakan bagian dari usaha Gerakan Teosofi dalam mewujudkan persaudaraan universal di antara umat manusia dengan tanpa memandang ras, bangsa, warna kulit dan agama. Teosofi menyandarkan ideologinya tentang hal ini melalui mistik agama-agama. Sekali lagi, kaum teosofi menegaskan bahwa semua agama adalah benar, sederajat dan sama-sama berasal dari Kenyataan Ilahi. Karena doktrin ini, seorang teosof tidak suka merendahkan atau menghina agama lain yang berbeda dan tidak setuju jika ada orang berpindah agama. Konversi agama hanya terjadi jika seseorang itu tidak mengerti akan kemuliaan dan keagungan agamanya. Karena doktrin ini pula teosofi menghendaki: "pemandangan persatoean" dan "persaudaraan" seloeroeh doenia. ${ }^{56}$ Jika setiap orang saling menghina atau merendahkan keyakinan orang lain yang berbeda, sulit terjadi persatuan dan persaudaraan kemanusiaan itu.

\section{Soal Perbedaan Agama}

Sedari awal, kaum teosofi Indonesia memahami bahwa bentuk, institusi dan wajah agama-agama berbeda satu sama lain. Mengapa "badan" agama-agama itu berbeda? Jawaban mereka sederhana saja:

Tjoemah sadja dari sebab samoea Roesoel itoe lahirnja didoenia ada djamannja sendiri, djadi bagi kelahirannja sarak (syari'at) djoega ada jang berbeda, karena satoe-satoe djaman, keadannja dari pikirannja manoesia djuga tida sama. ${ }^{57}$

Jadi, perbedaan konteks di mana para utusan Tuhan dan turunnya wahyu maka agama menjadi beragam pula. Argumen logis ini juga digunakan oleh kaum pluralis dan para pendukung filsafat perenial. Dalam bahasa MTI yang lain, karena bentuk (form, vorm) kelahiran agama berbeda-beda sesuai dengan kultur

55Latief "Faedah ..., 31.

${ }^{56}$ Ibid., 11.

${ }^{57}$ Siswosoeparto, “Kabar dari M 7,” dalam PTHN (1912), 140. 
masing-masing, maka bentuk "Kenyataan" juga berbeda-beda. ${ }^{58}$ Inilah yang membuat doktrin dan syariat menjadi beragam dan berbeda. Hal itu wajar karena agama turun bukan di ruang yang hampa sejarah. Syariat agama biasanya hadir sebagai respons terhadap situasi dan kondisi zaman. ㅍasan ㅂanafí, seorang intelektual Muslim kenamaan dari Mesir, menyatakan bahwa wahyu bukanlah sesuatu yang berada di luar konteks yang kokoh tak berubah, melainkan berada dalam konteks yang mengalami perubahan demi perubahan. ${ }^{59}$ Karena itu, keragaman ras, bangsa, suku bahkan perbedaan ruang dan waktu meniscayakan adanya perbedaan syariat. Sejauh menyangkut aturan-aturan rinci, tak mungkin ada ajaran tunggal dan universal yang bisa dipakai di setiap masa, situasi, dan kondisi. ${ }^{60}$

Seorang penulis teosofi merujuk kepada cerita tentang empat orang buta yang memegang gajah lalu membuat kesimpulan tentang gajah. Cerita ini sesungguhnya dipopulerkan oleh Rūmī (1207-12) seorang sufi dari Konya, Turki sekarang. ${ }^{61}$ Tentu saja, hasil rabaan setiap orang buta yang bersifat parsial itu akan melahirkan pemahaman yang parsial pula tentang gajah. Namun, mereka mengklaim telah memahami gajah (baca: agama) secara utuh. Dari sini seringkali muncul konflik dan perselisihan. ${ }^{62}$

Menurut kaum teosofi, Tuhan menurunkan atau memperbarui wahyu-Nya kepada masyarakat yang sakit yang memang membutuhkan. Sakitnya satu masyarakat dengan yang lain mungkin berbeda, karena itu obatnya (syariat) harus berbeda pula, tidak mungkin sama, mereka membuat tamsil:

Tabiatnja seorang Iboe memelihara anak-anaknja jang sama sakit itoe tidak sama; jang seorang diberi nasi dengan kare, jang kedoea boeboer sagoe dan garoet, jang ketiga roti dengan mentega. Demikian djuga kehendak Toehan adanja Ia mengadakan roepa-roepa agama itoe hanja

${ }^{58}$ N., "Sekarang Datang Swara Baroe, Apa Soedah Tahoe?” dalam PTBI (1929), no. 10, 147.

${ }^{59}$ Hasan Hanāfī, Dirāsat Islämiyyat (Mesir: Maktabah al-Anjalū alMishriyyah, t.t.), 71.

${ }^{60} \mathrm{Abd}$. Moqsith Ghazali, Argumen Pluralisme Agama: Membangun Toleransi Berbasis Al-Qur'an (Depok: KataKita, 2009), 166.

${ }^{61}$ Jalaluddin Rūmī, The Matsnawi of Jalal al-Din Rumi, ter. \& ed. Reynold Nicholson (England: E.J.W. Gibb Memorial Trust, 1990), Book III, 71-72.

${ }^{62}$ Baehler, "Gadadhara ..., 50. 
soepaja djadi djalannja masing-masing bangsa menoeroet tabiat jang setoedjoe dengan kodratnja sendiri-diri, boeat berbakti kepada Toehan. ${ }^{63}$

Maka, setiap bangsa memilki ajaran yang unik yang cocok bagi diri mereka masing-masing. Setelah dirasa cocok, setiap pemeluk agama harus teguh menjalankan ajaran, kewajiban dan aturan agama masing-masing dengan bebas dan saling menghormati satu sama lain. ${ }^{64}$

\section{Soal Penghinaan Agama, Konversi, dan Kerukunan}

Dalam konteks ini, kaum teosofi sangat tidak suka dengan perkataan dan sikap yang merendahkan, menjelekkan dan menghina agama orang lain yang berbeda. Ada empat (4) prinsip utama kaum teosofi tentang keberadaan banyak agama dan sikap terhadap agama orang lain. Pertama, ada ribuan agama yang cocok bagi bangsanya masing-masing, karena keunikan dan kecocokan kultur itu, maka tidak ada agama yang lebih tinggi dan lebih bagus dari yang lain, dus setiap agama pasti mengandung kebaikan, kemuliaan dan tujuan akhir yang sama. ${ }^{65}$ Dari sini berarti semua agama sederajat. Kyai Somo Citro, lagilagi dengan merujuk kepada kaum Sufi Muslim, menuliskan sikapnya:

Djadi setoedjoe dengan perkata'an-perkata'an ahli soefi, bahwa semoea agama itoe satoe toedjoean. Dari sebab itoe, barangsiapa mempeladjari theosofie, soedah tentoe akan lebih teguh perdjalanannja dan akan lebih dalam pengertian dalam agamanja sendiri, apa poela akan tidak mentjela pada lain agama dan kedjadiannja akan menambah keslametan dalam doenia. ${ }^{66}$

Kedua, sangat tidak pantas jika seseorang membenci dan menghina agama orang lain hanya karena perbedaan keyakinan, apalagi orang tersebut belum mendalami hakekat agamanya sendiri dan belum mempelajari agama yang dicelanya-dengan alasan "haram" mempelajari agama orang lain. Orang yang menghina agama lain disebut oleh kaum teosofi sebagai "Si

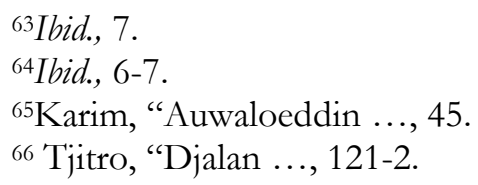


picik" yang tidak luas dan tidak dalam pengetahuan agamanya. A. Karim, seorang penulis Muslim menunjukkan kekesalannya sebagai berikut:

Agama itoe berpangkat-pangkat, menoeroet orang jang memakainja. Orang, selamanja memudji agamanja sendiri sadja, dan lebih adjaib sekali, agama jang lain ditjatjatnja, pada halnja ia beloem pernah memeriksa agama-agama jang lain; konon katanja haram. Perkataan itoe hamba pandang hanja oleh kepitjikan ilmoe sadja, sebagai katak dibawah tempoeroeng ${ }^{67}$

Jika dia Muslim, Kristen atau pengikut Hindu berarti ia belum mendalam pengetahuan agamanya. ${ }^{68}$ Kaum teosofi meyakini jika seseorang telah sampai pada esensi terdalam dari agamanya, ia tidak akan menghina dan membeda-bedakan agama. ${ }^{69}$

Ketiga, kasih sayang dan keadilan Tuhan untuk semua orang, bukan hanya untuk satu orang atau satu bangsa saja. Kaum teosofi meyakini jika ada seseorang yang berkeyakinan bahwa hanya dia yang dibimbing Tuhan sedangkan yang lain tidak; hanya suara dia yang merdu dan fasih ketika berdoa yang didengarkan Tuhan, sedangkan doa dan harapan orang lain yang hening tak bersuara tak akan diperdulikan Tuhan, sungguh orang tersebut tidak meyakini akan keadilan dan kekuasaan Tuhan dan menyangka Tuhan buta dan tuli. Jika ada orang yang gampang memvonis orang lain sebagai "sesat" berarti ia lebih tahu dari Tuhan, menurut kaum teosofi, justru orang itulah yang patut dikasihani dan akan menderita akibat perbuatannya itu. ${ }^{70} \mathrm{Hanya}$ Tuhan saja yang lebih tahu agama yang sah, baik, benar dan

${ }^{67}$ Karim, “Auwaloeddin ..., 101.

${ }^{68}$ Tjantoela, "Peringetan ..., 53. Seorang anggota teosofi lainnya yang beragama Islam menulis,"...adanja tjela menjtela dari sesoetoe fihak kepada lain fihak itoe tiada lain tjoema terbawa dari koerang fahamnja masingmasing, atau oleh karena marika itoe beloem menjelidiki maksoednja agamaagama tadi sehingga tertib." Broto, "Tentang Agama Islam dalam Theosofie," dalam PTHN (1926), no. 9, 125. 23.

${ }^{69}$ A. Rivai, "Kedatangan Goeroe (Mahdi)," dalam PTHN (1927), no. 2,

${ }^{70}$ A. Karim, "Serba-serbi tentang Allah," dalam PTHN (1925), no. 2, 31. 
utama, sedangkan pengetahuan manusia akan hal itu selalu menimbulkan perselisihan. ${ }^{71}$

Keempat, menurut Dirk van Hinloopen Labberton, seorang tokoh kunci Gerakan Teosofi Indonesia, sikap yang baik adalah mempelajari agama orang lain; sikap yang sangat baik adalah mendalami agamanya sendiri lalu mempraktekkannya dalam halhal yang baik; sikap yang sangat keliru adalah merayu, membujuk bahkan memaksa orang lain untuk mengikuti agamanya. Sikap yang tak dapat diampuni adalah memakai agamanya sebagai senjata untuk membodohi dan membuat orang lain menjadi fanatik buta. $^{72}$

Orang-orang teosofi sangat tidak menghendaki konversi agama. Dalam banyak kesempatan mereka menegaskan bahwa para pemeluk agama-apalagi anggota teosofi-- mestinya tidak boleh pindah agama. Orang harus setia dengan syariat atau ajaran agama masing-masing. Seorang teosof Muslim menyebut yang pindah agama sebagai orang yang musyrik atau mangkir, katanya:

Bagi Boemipoetera jang soedah berigama Islam laloe berpindah ke Christen atau Boeda itoe sebetulnja tidak boleh, begitoepoen sebaliknja, malah lebih dalam, orang jang bertabiat demikian itoe diseboet mosrik (moengkir), lahirnja melambatkan perdjalanan, karena masing-masing igama itoe hanja roepa-roepa djalan oentoek berbakti kepada Toehan(Toehan hanja Satoe)—kembali kepada Toehan, dalilnja al-Koran: Inna lillabi wa Inna Ilaibi raji'un. ${ }^{73}$

Selain menegaskan bahwa teosofi bukan sebuah agama atau agama baru, ${ }^{74}$ teosofi dan ajaran-ajarannya tidak hendak

${ }^{71}$ Tjantoela, "Peringetan ..., 55.

72 Labberton, "Perdamian ..., 126.

${ }^{73 R}$.Dj. "Tak ada judul," dalam PTHN (1918), no. 1, 41. Mengenai semua tujuan hanya kepada Tuhan lihat pula Baehler, "Gadadhara ..., 51, dan V.H. labberton, "Kenjatannja Tetenger Dan Perlambang," dalam PTHN (1917), no 11, 161, dan lain-lain.

${ }^{74}$ MTI dalam banyak publikasi mereka menegaskan bahwa teosofi bukan agama baru, bukan suatu agama dalam pengertiannya yang umum dan dalam pengertian agama sebagai seperangkat sistem. Kijahi Somo Tjitro, "Djalan Menoentoet Elmoe Kenjataan," dalam PTHN (1915), no. 10, 121 22. A. Latief, "Faedah Theosofie Boeat manoesia," dalam PTHN (1925), no. 12, 186. Terdapat banyak tuduhan bahwa teosofi adalah agama baru yang menyesatkan, atau sebagai agama Islam, Kristen, Hindu dan lain-lain, tetapi 
membuat "murtad" dan memindahkan agama seseorang ke agama lain. Perhimpunan ini menginginkan para pemeluk agama-sebagai anggota-anggotanya - untuk meyakini betul agama masing-masing dengan cara mempelajari maksud dan inti ajaran nabi masing-masing serta hidup rukun dalam kebersamaan meskipun berbeda agama dan keyakinan. ${ }^{75}$ Menurut klaim MTI, pada kenyataannya, alih-alih terjadi konversi, teosofi justru memperkuat keyakinan keagamaan seseorang dan para pengikut teosofi tetap setia dengan (syariat) agama-agama masing namun dalam pemahamannya yang mistikfilsufis yang melampaui (beyond) makna-makna lahiriah semata. Teosofi membuka mata hati para pemeluk agama untuk mengenal lebih dalam agama masing-masing yang belum pernah diketahui sebelumnya, bahkan-dalam beberapa kasusmenolong orang untuk taat beribadah sesuai keyakinannya. Bahkan ada kasus seseorang hendak murtad dari agamanya, tetapi guru teosofi menjelaskan kebenaran dan kenyataan agamanya hingga ia urung menjadi murtad. ${ }^{76}$

Perbedaan agama berarti jalan-jalan beragam menuju Tuhan. Dengan mengutip ayat dalam Bhagawadgita yang berbunyi, "Manusia itu datang kepada-Ku menurut beberapa jalan, dan jalan manapun seorang manusia datang kepada-Ku, Aku terima ia pada jalan itu karena semua jalan itu milik-Ku," 77 dan ayat al-Qur'an yang berbunyi, "Bagi pemeluk tiap-tiap agama, Kami sudah tetapkan aturan tertentu yang harus diikuti mereka sebaik-baiknya, janganlah mereka berbantah perkara itu denganmu, tetapi ajaklah mereka kepada Tuhanmu karena sesunggubnya engkau berada pada petunjuk dan jalan yang lurus,"78 kaum teosofi meyakini bahwa perbedaan jalan bukan hal yang prinsip dan fundamental tetapi tujuanlah yang utama dan tujuan semua jalan pasti kepada Tuhan Yang Sama jua. Seorang

menurut A. Latief tuduhan itu tidak berdasar fakta dan realita. Lihat A. Latief, "Faedah Theosofie Boeat manoesia," dalam PTHN (1926), no. 1, 31.

${ }^{75}$ Guldenaar, "Perhimpunan ..., 3, 14. C.W. Leadbeater, "Theosofie itoe apa?," dalam PTHN (1915), no. 2, 19-20.

${ }^{76}$ Leadbeater, “Theosofie ..., 20. Labberton, "Perdamian ..., 160.

${ }^{77}$ Latief, "Faedah ..., 30.

78P.A., "Takdir," dalam PTHN (1926), no. 1, 12-3. 
penulis Muslim lainnya anggota teosofi dari Bogor bernama Broto menegaskan:

Adapoen agama itoe adalah beberapa matjam; akan tetapi semoea itoe hanjalah mempoenjai satoe maksoed atau satoe jang ditoedjoenja, jaitoe Sang Hidoep. Maka jang kelihatan berbeda-beda itoe melainkan djalannja sadja. ${ }^{79}$

Pendapat serupa juga ditunjukkan oleh Louis Baehler, katanya:

Adapoen roepa-roepa agama itoe lain tidak hanja beberapa djalan jang menoedjoe pada jang Maha Koewasa. Banjak dan berbeda-beda sekali djalan-djalan jang dapat menoedjoe Tjandi Kali di Kalighat (deket Kalkoeta). Begitoepeon banjak poela djalan ke Ka'batoe'llah. Satoesatoe igama ialah satoe djalan kepada Allah. ${ }^{80}$

Jika pluralisme agama bermakna "satu Tuhan banyak agama," "satu Tuhan disebut dengan banyak nama disembah dengan berbagai cara," "banyak jalan menuju Tuhan," atau "jalan-jalan mengantarkan ke puncak yang sama," atau "jalanjalan yang berbeda mengantarkan ke tujuan yang sama, "agamaagama yang berbeda adalah jalan-jalan yang memiliki validitas yang sama menuju kepada Tuhan yang sama," "agama-agama yang berbeda bicara tentang yang berbeda (dengan bahasa yang berbeda pula) namun memiliki kebenaran yang sama," 81 maka itulah pandangan dan sikap yang dianut MTI pada sekitar satu abad yang lalu, jauh sebelum tokoh-tokoh pluralis di Barat dan para sarjana Muslim Indonesia mengumandangkan hal serupa.

Dengan kesadaran ini, perbedaan semestinya tidak menjadi bibit konflik dan perselisihan. Secara spesifik, kaum teosofi menyoroti satu aspek teologis yang sering memicu konflik, yaitu

\footnotetext{
${ }^{79}$ Broto, "Tentang Agama Islam dalam Theosofie," dalam PTHN (1926), no. 9, 125.

${ }^{80}$ Baehler, "Gadadhara ..., 98.

${ }^{81}$ Mengenai adagium-adagium itu dapat dibaca pada Paul F. Knitter, No Other Name? A Critical Survey of Christian Attitudes toward the World Religions (1985); Seyyed Hossein Nasr, Knowledge and the Sacred (Albany, New York: State University of New York Press, 1989); Knitter, One Earth Many Religions: Multifaith Dialogue and Global Responsibility (1995). Paul F. Knitter, ed.,The Myth of Religious Superiority, Multifaith Explorations of Religoius Pluralism (Maryknoll, New York: Orbis Books, 2005). Knitter, Introducing Theologies of Religions (2003), dan lain-lain.
} 
perasaan superioritas satu agama atas yang lain. Perasaan dan sikap itu sering ditonjolkan dalam interaksi sosial berbarengan dengan sikap menghina atau merendahkan keyakinan orang lain, ${ }^{82}$ dan dicarilah ayat kitab suci atau legitimasi agama untuk menyerang agama lain yang dianggap salah. ${ }^{83}$ Menurut seorang penulis Muslim, jika seseorang menganut agama dan mempraktekannya namun buahnya adalah permusuhan dan perselisihan berarti orang tersebut keliru dalam memahami dan mempraktekan agamanya. Sikap ini harus segera diubah. ${ }^{84}$ Menurut kaum teosofi, salah satu cara terbaik meminimalisir konflik dan perselisihan antar pemeluk agama adalah menonjolkan paham dan sikap bahwa semua agama bertujuan baik dan mulia; semuanya adalah cara dan jalan yang beragam menuju Tuhan Yang Esa. ${ }^{85}$

Seorang anggota teosofi yang lain mengingatkan para pemeluk agama untuk tidak berdebat atau berbantah-bantahan mengenai perbedaan agama, karena alih-alih menemukan kebenaran dan kedamaian hal itu sering memicu konflik. Mengapa? Karena setiap orang telah memiliki kepercayaan suci masing-masing. Dengan perdebatan di mulut saja (debat kusir) sulit ditemukan mana yang benar dan mana yang salah, yang muncul selamanya adalah perselisihan. Seharusnya setiap orang menghormati dan membiarkan orang lain berkeyakinan dan mempraktekkan agamanya. Justru dengan berpikir jernih dan mau memahami agamanya secara mendalam, seseorang akan sadar bahwa berbantah-bantahan tak ada gunanya. ${ }^{86}$

Menurut A. Latief, seorang penulis Muslim dan anggota teosofi, pemahaman Islam yang mendalam pasti akan cocok dengan doktrin teosofi, dan jika seseorang ingin meneliti tematema mengenai persaudaraan di dalam kitab suci agama-agama, maka ia akan menemukan ayat-ayat mengenai kesatuan esensial

${ }^{82}$ N., "Sekarang Datang Swara Baroe, Apa Soedah Tahoe?" dalam PTBI (1929), no. 10, 147. Tjantoela, "Peringetan ..., 53.

${ }^{83}$ Latief, "Faedah ..., 11.

${ }^{84}$ R.Dj. "Tak ada judul," dalam PTHN (1918), no. 1, 41.

85Pitjik, "Membandingkan ..., 104.

86Baehler, "Gadadhara ..., 7. 
agama-agama dan persaudaraan umat manusia. ${ }^{87}$ Seseorang hanya akan menemukan dua tema itu jika ia mampu menembus aspek terdalam ajaran kitab-kitab suci. Jika tidak, maka yang ditonjolkan adalah perbedaan dan pertentangan keyakinan agama, dan hal inilah yang sering memicu konflik. Karena tujuan pokok Gerakan Teosofi adalah persaudaraan universal dan perdamaian maka para anggotanya dan semua penganut agama dianjurkan untuk menonjolkan kedua aspek itu ketika mempelajari agama-agama.

Ketika membicarakan hubungan antaragama dan pentingnya orang memahami agamanya dan agama orang lain sehingga muncul respek satu sama lain, Labberton menegaskan bahwa bagi orang Hindia Belanda (Indonesia) hanya ada dua jalan buat kemajuan mereka: pertama, bersama-sama orang Belanda mempelajari berbagai ilmu pengetahuan hingga sejajar dengan orang-orang Eropa, kedua, dengan cara berperang melawan bangsa lain yang tak sebanding (mungkin maksudnya Belanda). Jalan yang pertama akan menghasilkan perdamaian dan keamanan, dan cara yang kedua akan memunculkan perang dan kebinasaan. Terserah kepada orang Hindia; mau memilih konflik atau persaudaraan, perang atau perdamaian, binasa atau kemajuan. Menurut Labberton, bangsa Eropa, Tionghoa dan Jawa yang telah memilih jalan kedua sesungguhnya telah menjadi kawan atau tentaranya "Sang Ijajil" (mungkin maksudnya Dajjal), sedangkan yang memilih jalan pertama akan jadi tentaranya Sri Tunjung Seto-Sang Guru Dewa, Rajanya Dunia ketentraman. ${ }^{88}$

Seorang anggota teosofi Muslim, Raden Djojosoediro mengingatkan kaum Muslim untuk tidak "cemburu" ketika ada sesama Muslim yang pindah agama. Persoalan konversi agama ini, terutama dikalangan kaum Muslim sering menimbulkan konflik baik intra maupun antar pemeluk agama. Menurut Djojosoediro, konflik--baik karena konversi atau hal yang lain biasanya muncul dari kalangan "kaoem-kaoem jang rendah,"

87Latief, "Faedah ..., 10.

${ }^{88}$ Labberton, "Perdamian ..., 126-7. Pernyataan Labberton ini cukup menjadi penunjuk bahwa Gerakan Teosofi di Indonesia pada masa itu memang menjadi alat "politik etis" Belanda dalam meredam perlawanan dari rakyat (beragama) Indonesia. 
mungkin maksudnya yang rendah pendidikannya. Sementara bagi anggota teosofi yang terpelajar harus dapat hidup bersama dalam guyub dan rukun meski ada perbedaan. Kaum Muslim mesti meneledani Nabi Muhammad yang tidak gampang "cemburu" dan berkonflik dengan orang lain, tetapi lebih banyak menonjolkan welas asih. Djojosoediro memberi contoh negeri India dalam hal kerukunan umat beragama. Di negeri ini-(pada masa itu, pen.)—berbagai macam bangsa dan ruparupa agama dapat hidup rukun saling menghormati, menghargai dan setiap pemeluk agama bebas menjalankan keyakinannya. India telah membuktikan bahwa adanya perbedaan agama dan keyakinan tidak serta-merta melahirkan konflik dan pertikaian. ${ }^{89}$

Kebebasan beragama merupakan hal yang paralel dengan konsep dan paham teosofi mengenai kesederajatan agamaagama. Tentu saja, teosofi dengan segala doktrinnya tentang kesatuan dan titik-temu agama-agama sangat mendukung aturan dan praktek kebebasan beragama. Kaum teosofi sangat setuju dengan peraturan yang dibuat pemerintah Belanda dalam pasal $\mathrm{X}$ (10) mengenai agama yang menyebutkan bahwa "Tidak boleh memaksa orang lain dalam hal berpikir dan agama. Semua manusia merdeka untuk beribadah kepada Tuhan masingmasing. Hari-hari raya semua agama diakui. Tidak boleh menghina atau mengurangi hak semua agama...dan jangan sampai membuat kesedihan dan kesusahan kepada orang lain. Semua pengajar agama dan ulama tidak mendapat bayaran dari negara." 90 Tidak diketahui kapan undang-undang ini dibuat dan disahkan oleh pemerintah Belanda, namun kaum teosofi mempublikasikannya pada tahun 1921 dengan klaim bahwa pemerintahan yang dibentuk Belanda ternyata berdasar persaudaraan atau perdamaian, dan itu sesuai dengan doktrin inti Gerakan Teosofi.

\section{Catatan Akhir}

Mungkin MTI adalah fakta sejarah yang telah memberi petunjuk dengan jelas bahwa pemahaman keagamaan yang

${ }^{89}$ R.Dj. "Tak ada judul," dalam PTHN (1918), no. 1, 42.

${ }^{90 R e d a k s i, ~ " P e m e r i n t a h a n ~ J a n g ~ B e r d a s a r ~ P e r s o e d a r a a n ~ A t a u ~}$ Perdamaian," dalam PTHN (1921), no. 6, 96. 
mendalam telah melahirkan pandangan dan sikap-sikap keagamaan yang inklusif-pluralis yang akan membawa angin segar bagi hubungan harmoni antarpemeluk agama di Nusantara. Pandangan keagamaan yang mendalam dan wawasan yang luas, pada MTI misalnya, tentu lahir sebagai hasil dari pergumulan banyak ide dan perjumpaan dengan bangsa-bangsa: Eropa, Amerika, India, Cina dan kekayaan kultur bangsa sendiri.

Indonesia hari ini yang ditandai dengan menguatnya fundamentalisme keagamaan yang cenderung intoleran dan eksklusif, adalah Indonesia yang telah kehilangan kedalaman beragama dan jati dirinya sebagai negeri yang sesungguhnya subur dengan budaya kerukunan, tenggang rasa dan kedamaian. Dalam konteks inilah, pandangan-pandangan keagamaan MTI layak untuk direnungkankan kembali, karena nurani keagamaan sejatinya selalu condong kepada harmoni dan toleransi tanpa harus tercerabut dari keyakinan dan identitas masing-masing yang otentik. Wa al-Lāh a lam bi al-sawāb.

\section{Daftar Pustaka}

Anonim. 1915. Woedjoed-Woedjoed Moelia. PTHN.

1920. Goenanja Roepa-Roepa Pengadjaran Didalam Kitab-Kitab Tasaoef. PTHN. . 1926. Theosofie. PTHN.

Artawijaya. 2010. Gerakan Theosofi di Indonesia, Menelusuri Jejak Aliran Kebatinan Yabudi Sejak Masa Hindia Belanda Hingga Era Reformasi. Jakarta: Pustaka Al-Kautsar.

Baehler, Louis A. 1916. Gadadhara atau Ramakrisjna. PTHN, no. 7 .

. 1917. Gadadhara atau Ramakrisjna. PTHN, no.

4.

Blavatsky, Helena Petrovna. 1981. The Key to Theosophy. USA: Theosophical University Press.

Broto. 1926. Tentang Agama Islam dalam Theosofie. PTHN, no. 9.

Cranston, Sylvia. 1993. The Extraordinary Life and Influence of Helena Blavatsky, Founder Of The Modern Theosophical Movement. California: Path Publishing House. 
De Tollenaere, Herman Arij Oscar. 1996. The Politics of Divine wisdom, Theosophy and Labour, National, and Women's Movements in Indonesia and South Asia 1857-1947. Leiden: Universiteit Nijmegen.

. 2000. Indian Thought in the Dutch Indies: The Theosophical Society. IIAS Newsletter Online, no. 23.

Derun. 1954. Meditasi Untuk Permulaan (II). PTTI, no. 27.

Djojodiredjo, Rd. 1918. "[tak ada judul].” PTHN, no. 1. . 1912. Wadjibnja Orang Hidoep. PTHN.

H.E. van Motman, H.E. 1912. Kepada Toean redacteur soerat kabar Pewarta Theosophie. PTHN.

Hanafī, Hasan. Dirāsat Islämiyyāt. Egypt: Maktabah al-Anjalū alMishriyyah.

Hidayat, Komaruddin dan Nafis, Muhammad Wahyuni. 2003. Agama Masa Depan: Perspektif Filsafat Perennial. Jakarta: Gramedia.

J.M. 1920. Hal Rasoelallah. PTHN. . 1922. Satoe Pokok. PTHN, no. 1-2.

Karim, A. 1923. Auwaloeddin ma'rifatoellah. PTHN, no. 3. 1925. Serba-serbi tentang Allah. PTHN, no. 2.

Khan, Inayat. 1922. Soefie. PTHN, no. 5.

Labberton, van Hinloopen. 1912. Perdamian Doenia (sic.). PTHN.

PTHN, no. 11.

. 1917. Kenjatannja Tetenger Dan Perlambang.

. Perdamian sadoenia. TINI.

Latief, A. 1925. Faedah Theosofie Boeat manoesia. PTHN, no. 12. no. 1. 1926. Faedah Theosofie Boeat manoesia. PTHN, 1922. Ada. PTHN, no. 5.

Leadbeater. C. W. 1915. Kitab Theosofie. PTHN. . 1915. Theosofie itoe apa?. PTHN, no. 2.

Mangoenpoerwoto. 1920. Sikap Theosophie Kepada Kemadjuan Oemoem. PTHN, no. 1.

N. 1927. Djagad Goeroe. PTHN, no. 8. . 1927. Seng-To! Kow-Li!. PTHN. 
. 1929. Sekarang Datang Swara Baroe, Apa Soedah

Tahoe?. PTBI, no. 10. 1930. Djalannja Mentjarik Ingsoen. PTBI, no. 3.

Nugraha, Iskandar. 2011. Teosofi, Nasionalisme \& Elite Modern Indonesia. Depok: Komunitas Bambu.

P.A. 1926. Takdir. PTHN, no. 1.

Redaksi. 1921. Pemerintahan Jang Berdasar Persoedaraan Atau Perdamaian. PTHN, no. 6.

Rumi, Jalal al-Din. 1990. The Matsnawi of Jalal al-Din Rumi, translated and edited by Reynold Nicholson. England: E.J.W. Gibb Memorial Trust. Book III.

S. Si Pitjik. 1926. Membandingkan Agama. PTHN, no.7.

S.M. 1926. Djalan Kesempoernaan. PTHN, no. 10.

Siswosapoetro. 1916. Jang Bekerdja Boeat Loge dan Theosofische Vereeniging. PTHN, no. 4. 1912. Kabar dari M 7. PTHN.

Tjantoela. 1912. Peringetan bab empat warna orang manoesia. PTHN.

Tjitro, Kijahi Somo. 1915. Djalan Menoentoet Elmoe Kenjataan. PTHN, no. 10.

TVTKL, Lid. 1927. Katerangan Dari Goeroe Kita. PTHN, no. 1.

W.N. Guldenaar, W.N. 1916. Perhimpoenan Tasaoef. PTHN, no. 3.

Wongsodilogo. R.M. 1921. Djalan Oetama. PTHN. 